\title{
Complementary and Alternative Medicine: Impact of Biofield Energy Treatment on the Physicochemical and Thermal Properties of
}

\section{Withania somnifera Root Extract}

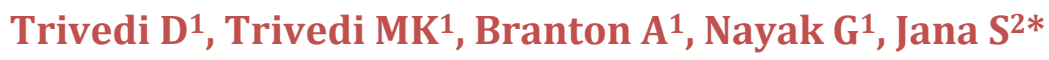 \\ ${ }^{1}$ Trivedi Global, Inc. Henderson, USA \\ ${ }^{2}$ Trivedi Science Research Laboratory Pvt Ltd, India
}

${ }^{*}$ Corresponding author: Snehasis Jana, Trivedi Science Research Laboratory Pvt Ltd, Bhopal, India, Tel: +91-022-25811234; Email: publication@trivedieffect.com

\section{Research Article \\ Volume 3 Issue 1}

Received Date: January 18, 2019

Published Date: February 05, 2019

DOI: $10.23880 /$ jonam-16000167

\section{Abstract}

Withania somnifera (WS) is a popular health supplement, which is used in many neutraceutical and pharmaceutical formulations for the overall good health, improves the quality of life, along with the prevention and treatment of numerous diseases. In this study, the impact of the Consciousness Energy Healing Treatment (the Trivedi Effect ${ }^{\circledR}$ ) on the physicochemical and thermal properties of WS root extract was evaluated using modern analytical techniques. The test sample WS root extract was divided and termed as control and Biofield Energy Treated sample. The control sample did not receive the Biofield Energy Treatment; whereas, the treated WS root extract received the Consciousness Energy Healing Treatment by a well-known Biofield Energy Healer, Dahryn Trivedi. The particle size values of the treated WS root extract powder sample were altered by $-7.92 \%\left(d_{10}\right),-5.32 \%\left(d_{50}\right)$, and $-0.36 \%\left(d_{90}\right) 1.02 \%\{D(4,3)\}$; thus, the specific surface area was significantly increased by 5.31\% compared with the control sample. The evaporation temperature and latent heat of evaporation of the treated WS root extract were significantly increased by $11.24 \%$ and $21.34 \%$, respectively compared with the control sample. The total weight loss in the treated WS root extract was decreased by $4.3 \%$; however, the residue amount was significantly increased by $25.02 \%$ compared with the control sample. The experimental results concluded that the Trivedi Effect ${ }^{\circledR}{ }^{-}$Consciousness Energy Healing Treatment might have altered particle size, surface area, and thermal properties of WS root extract which would show better solubility, dissolution, absorption, bioavailability, and thermal stability compared to the control sample. This new form of WS root extract would be helpful to design more efficacious neutraceutical/pharmaceutical formulations for rejuvenate the body, restricting the aging process, immune busting, neuro-protection, antioxidant, inflammation, memory loss, insomnia, hepatoprotection, hypoglycemia, gastrointestinal issues, constipation, arthritis, cancer, skin conditions, Alzheimer's, Huntington's, and Parkinson's disorders, etc.

Keywords: Withania somnifera Root Extract; Complementary and Alternative Medicine; The Trivedi Effect ${ }^{\circledR}$; Consciousness Energy Healing Treatment; PSA; PXRD; DSC; TGA/DTG 


\section{Journal of Natural \& Ayurvedic Medicine}

Abbreviations: PSA: Particle Size Analysis; PXRD: Powder X-Ray Diffraction; DSC: Differential Scanning Calorimetry; TGA: Gravimetric Analysis; DTG: Differential Thermo Gravimetric Analysis.

\section{Introduction}

Withania somnifera (WS) popularly known as ashwagandha/ Indian ginseng. The WS root extract is a popular ingredient in the neutraceutical/pharmaceutical supplements due to its multiple beneficial effects in the body, i.e., rejuvenate the body, acts as a tonic to arrest the aging process, boost the immune system, improves the overall quality of life, and help in the inhibition and treatment of various diseases [1-3]. WS root extract used for the treatment of sexual disorders, stress-related disorders, nervous and immunological disorders, diabetes, infectious diseases, arthritis, ulcer, cancer, etc. [2-6]. The WS root extract contains number of biologically active Phytoconstituents, i.e., withanolides (withanolide A, withanolide B, withanolide D, withferine, etc.), withanamides, alkaloids, sitoindosides, starch, reducing sugars, peroxidases, withanicil, glycosides, benzyl alcohol, dilcitol, 2-phenyl ethanol, benzoic acid, cinnamic acid, phenyl acetic acid, etc. [7-9]. Withanolides are reported with many important beneficial physiological actions, i.e., immunomodulating, neuroprotective, antioxidant, antiinflammatory, insomnia, memory loss, hepatoprotective, and hypoglycemic. It is also helpful in gastrointestinal problems, constipation, antiarthritic, antimicrobial, anticancer, skin conditions, Huntington's, Alzheimer's, and Parkinson's disorders, etc. [3-6,10-12].

The popularly of WS in the formulations is very high, but solubility, dissolution, absorption, and bioavailability of the neutraceutical compounds are very important to achieve better therapeutic efficacy [13, 14]. The Consciousness Energy Healing Treatment (the Trivedi Effect $^{\circledR}$ ) has the significant impact on the crystallite size, particle size, surface area, thermal properties, bioavailability, etc. of the neutraceutical and pharmaceutical compounds [15-19]. The Trivedi Effect ${ }^{\circledR}$ is a natural and only scientifically proven phenomenon in which a skilled person can harness this inherently intelligent energy from the "Universe" and can transmit it anywhere on the planet through the possible mediation of neutrinos [20]. The "Biofield" is a unique paradimensional electromagnetic field generated from the continuous movement of the electrically charged particles (ions, cells, etc.) in the body. The "Biofield" based Energy Healing Therapies have been accepted all over the world, which claimed to have significant outcomes against various disease conditions $[21,22]$. The National Institutes of Health (NIH) and National Centre for Complementary and Alternative Medicine (NCCAM) has recommended and included the Energy therapy under Complementary and Alternative Medicine (CAM) category that has been accepted by most of the USA population [23, 24]. Moreover, the Trivedi Effect $^{\circledR}{ }^{\circledR}$-Consciousness Energy Healing Treatment also have outstanding outcomes in different object (s), i.e., metals, ceramic, and polymer, organic compounds, crops, microorganisms, and cancer cells [25-34]. Seeing the significant results, this study was designed to evaluate the influence of the Trivedi Effect ${ }^{\circledR}$ Consciousness Energy Healing Treatment on WS root extract using particle size analysis (PSA), powder X-ray diffraction (PXRD), differential scanning calorimetry (DSC) analytical techniques, and thermo gravimetric analysis (TGA)/ Differential thermo gravimetric analysis (DTG).

\section{Materials and Methods}

\section{Chemicals and Reagents}

Withania somnifera root extract was purchased from Sanat Product Ltd., India and the other chemicals used during the experiment were purchased from India.

\section{Consciousness Energy Healing Treatment Strategies}

The test sample WS root extract powder was divided into two parts. One part of the WS root extract was received the Trivedi Effect $^{\circledR}$-Consciousness Energy Healing Treatment by a well-known Biofield Energy Healer, Dahryn Trivedi (USA) remotely for 3 minutes through the Unique Energy Transmission process termed as the Biofield Energy Treated sample. While the other part of the test sample did not receive the Biofield Energy Treatment called control sample. But, the control WS root extract was subjected to a "sham" healer under the similar laboratory conditions, who did not have any knowledge about the Biofield Energy Healing Treatment. Both the samples were kept in sealed conditions and further characterized by using modern analytical techniques.

\section{Characterization}

The PSA, PXRD, DSC, and TGA analysis of WS root extract was performed. The PSA was carried out using Malvern Mastersizer 2000 (the UK) with the help of the wet method $[35,36]$. The PXRD analysis of WS root extract was performed with the help of Rigaku MiniFlex-II Desktop X-ray diffractometer (Japan) [37,38]. The average size of the crystallite was calculated from PXRD data using the Scherrer's formula (1) 


\section{Journal of Natural \& Ayurvedic Medicine}

$$
\mathrm{G}=\mathrm{k} \lambda / \beta \cos \theta
$$

Where $\mathrm{G}$ is the crystallite size in $\mathrm{nm}, \mathrm{k}$ is the equipment constant, $\lambda$ is the radiation wavelength, $\beta$ is the full-width at half maximum, and $\theta$ is the Bragg angle [39]. Similarly, the DSC analysis of WS root extract was performed with the help of DSC Q200, TA instruments. The TGA/DTG thermograms of WS root extract were obtained with the help of TGA Q50 TA instruments $[35,36]$.

The $\%$ change in particle size, specific surface area, melting point, latent heat, weight loss, and the maximum thermal degradation temperature of the Biofield Energy Treated WS root extract sample was calculated compared with the control sample using the following equation 2 :

$$
\% \text { change }=\frac{[\text { Treated }- \text { Control }]}{\text { Control }} \times 100(2)
$$

\section{Results and Discussion}

\section{Particle Size Analysis (PSA)}

The comparative particle size analysis results of the control and the Biofield Energy Treated WS powder samples were presented in Table 1 . The particle size values of the control WS powder sample were $20.34 \mu \mathrm{m}$, $58.43 \mu \mathrm{m}, 119.86 \mu \mathrm{m}$, and $65.21 \mu \mathrm{m}$ at $\mathrm{d}_{10}, \mathrm{~d}_{50}, \mathrm{~d}_{90}$, and $\mathrm{D}(4,3)$, respectively. Similarly, the particle sizes of the Biofield Energy Treated WS root extract powder were $18.73 \mu \mathrm{m}, 55.32 \mu \mathrm{m}, 119.43 \mu \mathrm{m}$, and $65.87 \mu \mathrm{m}$ at $\mathrm{d}_{10}, \mathrm{~d}_{50}$, $\mathrm{d}_{90}$, and $\mathrm{D}(4,3)$, respectively. The particle size values in the Biofield Energy Treated WS root extract was decreased by $7.92 \%, 5.32 \%$, and $0.36 \%$ at $\mathrm{d}_{10}, \mathrm{~d}_{50}, \mathrm{~d}_{90}$, respectively whereas $1.02 \%$ increase at $D(4,3)$ compared to the control sample (Table 1). The specific surface area (SSA) of the treated WS root extract powder $\left(0.258 \mathrm{~m}^{2} / \mathrm{g}\right)$ was significantly increased by $5.31 \%$ compared with the control sample $\left(0.245 \mathrm{~m}^{2} / \mathrm{g}\right)$. The results indicated that the Trivedi Effect ${ }^{\circledR}$-Consciousness Energy Healing Treatment might be acting like an external force to break down the larger WS root extract powder particles to the smaller particle hence increased the surface area. Therefore, due to reduced particle size and increased surface area, the solubility, dissolution rate, absorption, bioavailability, and even the therapeutic efficacy of the Biofield Energy Treated WS root extract would be very high [37-39].

\begin{tabular}{|c|c|c|c|c|c|}
\hline Parameter & $\mathbf{d}_{\mathbf{1 0}}(\boldsymbol{\mu m})$ & $\mathbf{d}_{\mathbf{5 0}}(\boldsymbol{\mu m})$ & $\mathbf{d}_{\mathbf{9 0}}(\boldsymbol{\mu} \mathbf{m})$ & $\mathbf{D}(\mathbf{4 , 3} \mathbf{( \boldsymbol { \mu m } )}$ & $\mathbf{S S A}\left(\mathbf{m}^{\mathbf{2}} / \mathbf{g}\right)$ \\
\hline Control & 20.34 & 58.43 & 119.86 & 65.21 & 0.245 \\
\hline Biofield Energy Treated & 18.73 & 55.32 & 119.43 & 65.87 & 0.258 \\
\hline Percent change (\%) & -7.92 & -5.32 & -0.36 & 1.02 & 5.31 \\
\hline
\end{tabular}

Table 1: Particle Size Data of the Control and Biofield Energy Treated WS Root Extract.

$\mathrm{d}_{10}, \mathrm{~d}_{50}$, and $\mathrm{d}_{90}$ : particle diameter corresponding to $10 \%, 50 \%$, and $90 \%$ of the cumulative distribution, $\mathrm{D}(4,3)$ : the average mass-volume diameter, and SSA: the specific surface area.

\section{Powder X-ray Diffraction (PXRD) Analysis}

The PXRD diffractograms of both the control and Biofield Energy Treated WS root extract samples did not show any sharp and intense peaks (Figure 1), which indicated that both samples were amorphous in nature and the Biofield Energy Treatment did not alter the crystallinity pattern of the WS root extract compared to the control sample.
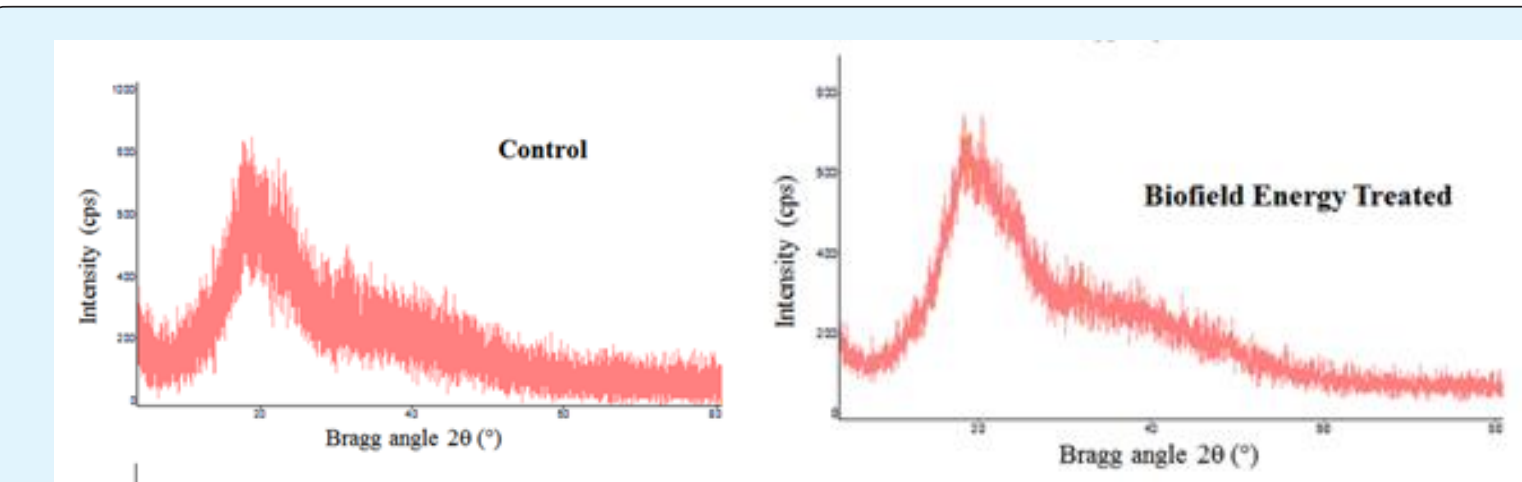

Figure 1: PXRD Diffractograms of the Control and Biofield Energy Treated WS Root Extract. 


\section{Differential Scanning Calorimetry (DSC) Analysis}

The DSC thermograms of the control and Biofield Energy Treated WS root extract samples showed an endothermic peak at $105.65^{\circ} \mathrm{C}$ and $117.52^{\circ} \mathrm{C}$ (Figure 2). Such an endothermic peak was due to the evaporation of the trapped water molecule from the samples. The evaporation temperature and latent heat of evaporation $\left(\Delta \mathrm{H}_{\text {evaporation }}\right)$ of the Biofield Energy Treated WS root extract were significantly increased by $11.24 \%$ and $21.34 \%$, respectively compared with the control sample (Table 2). As per the literature, any alteration in the molecular chains and the crystal structure has the direct connection to the latent heat of fusion [40]. Hence, Dahryn's Biofield Energy Treatment could have disrupted the molecular chains and crystal structure of WS root extract which lead to the increase of the melting point of the treated sample compared to the control sample.
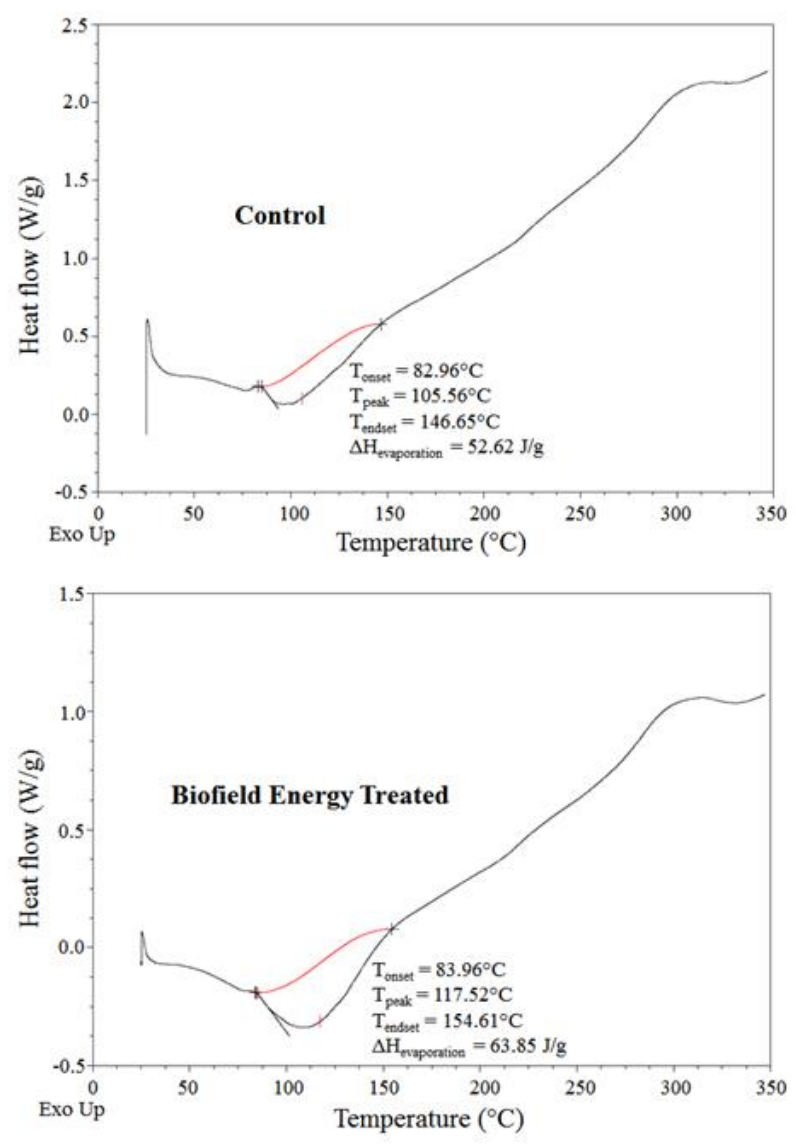

Figure 2: DSC Thermo grams of the Control and Biofield Energy Treated WS Root Extract.

\begin{tabular}{|c|c|c|}
\hline Sample & $\begin{array}{c}\text { Evaporation } \\
\text { Temperature }\left({ }^{\circ} \mathbf{C}\right)\end{array}$ & $\begin{array}{c}\Delta \mathbf{H}_{\text {evaporation }} \\
(\mathbf{J} / \mathbf{g})\end{array}$ \\
\hline Control Sample & 105.65 & 52.62 \\
\hline $\begin{array}{c}\text { Biofield Energy } \\
\text { Treated }\end{array}$ & 117.52 & 63.85 \\
\hline \% Change & 11.24 & 21.34 \\
\hline
\end{tabular}

Table 2: DSC data for both Control and Biofield Energy Treated samples of WS Root Extract.

$$
\Delta H_{\text {evaporation: Latent heat of evaporation. }}
$$

\section{Thermal Gravimetric Analysis (TGA) / Differential Thermogravimetric Analysis (DTG)}

The control and the Biofield Energy Treated WS root extract showed two steps of the degradation process in the thermograms. The total weight loss of the Biofield Energy Treated WS root extract (81.66\%) was decreased by $4.3 \%$ compared with the control sample (85.33\%). However, the residue quantity was significantly increased by $25.02 \%$ in the Biofield Energy Treated sample compared to the control sample (Table 3).

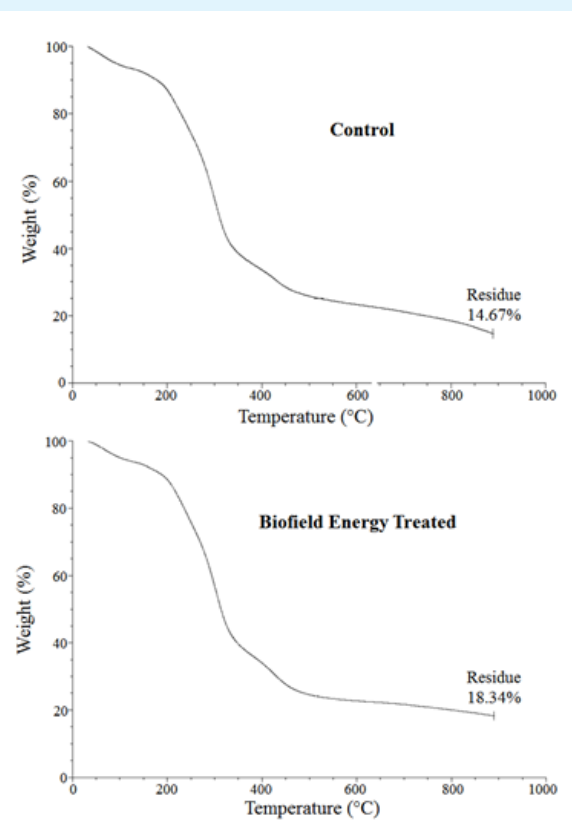

Figure 3: TGA thermograms of the control and Biofield Energy Treated WS root extract. 


\section{Journal of Natural \& Ayurvedic Medicine}
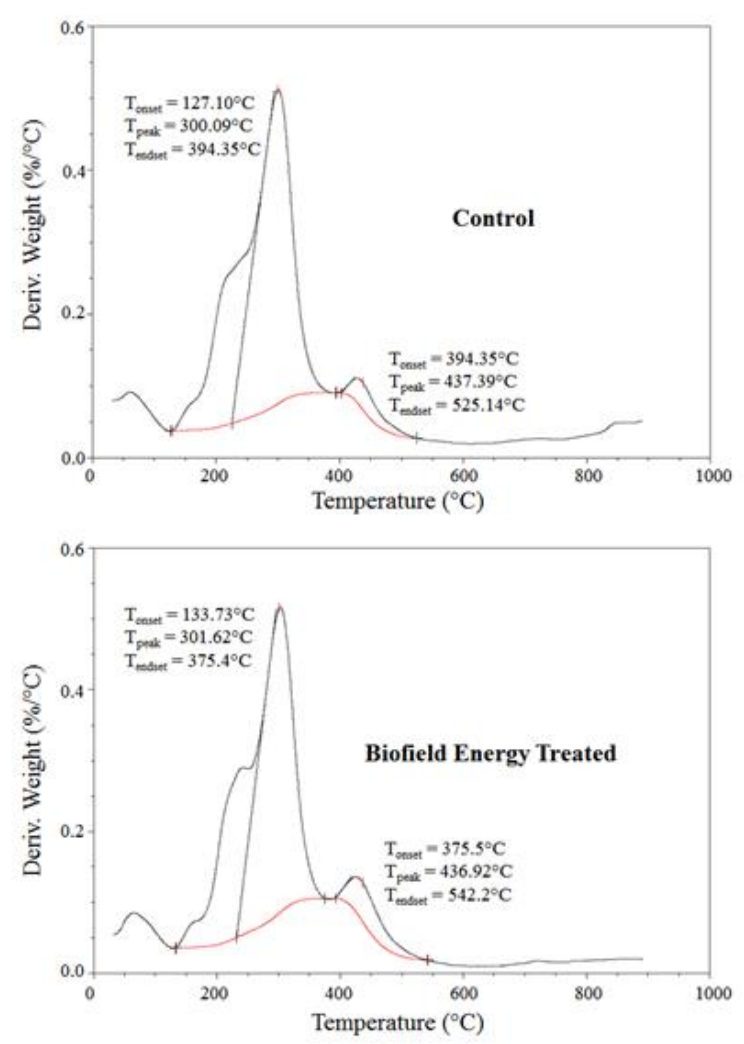

Figure 4: DTG Thermo grams of the control and Biofield Energy Treated WS Root Extract.

\begin{tabular}{|c|c|c|c|c|}
\hline \multirow{2}{*}{ Sample } & \multicolumn{2}{|c|}{ TGA } & \multicolumn{2}{c|}{ DTG; $\mathbf{T}_{\max }\left({ }^{\circ} \mathbf{C}\right)$} \\
\cline { 2 - 5 } & $\begin{array}{c}\text { Total weight } \\
\text { loss (\%) }\end{array}$ & $\begin{array}{c}\text { Residue } \\
\text { \% }\end{array}$ & Peak 1 & Peak 2 \\
\hline Control & 85.33 & 14.67 & 300.09 & 437.39 \\
\hline $\begin{array}{c}\text { Biofield Energy } \\
\text { Treated }\end{array}$ & 81.66 & 18.34 & 301.62 & 436.92 \\
\hline \% Change & -4.3 & 25.02 & 0.51 & -0.11 \\
\hline
\end{tabular}

Table 3: TGA/DTG Data of the Control and Biofield Energy Treated Samples of WS Root Extract.

$\mathrm{T}_{\max }=$ the temperature at which maximum weight loss takes place in TG or peak temperature in DTG.

Similarly, the control and the Biofield Energy Treated WS root extract also exhibited two peaks in the DTG thermograms (Figures $3 \& 4$ ). The maximum thermal degradation temperature $\left(\mathrm{T}_{\max }\right)$ of the Biofield Energy Treated WS root extract was slightly altered by $0.51 \%$ and $-0.11 \%$ in peak 1 and peak 2 , respectively compared with the control sample. Overall, TGA/DTG thermal analysis revealed that the thermal stability of the Biofield
Energy Treated WS root extract was increased compared with the control sample.

\section{Conclusion}

The experimental results indicated that the Trivedi Effect ${ }^{\circledR}$-Consciousness Energy Healing Treatment have a significant impact on the particle size, surface area, and thermal behaviors of WS root extract. The particle size values of the Biofield Energy Treated WS root extract powder sample were altered by $-7.92 \%\left(\mathrm{~d}_{10}\right),-5.32 \%$ $\left(\mathrm{d}_{50}\right)$, and $-0.36 \%\left(\mathrm{~d}_{90}\right) 1.02 \%\{\mathrm{D}(4,3)\}$; thus, the specific surface area was significantly increased by $5.31 \%$ compared with the control sample. The evaporation temperature and $\Delta \mathrm{H}_{\text {evaporation }}$ of the Biofield Energy Treated WS root extract were significantly increased by $11.24 \%$ and $21.34 \%$, respectively compared with the control sample. The total weight loss in the Biofield Energy Treated WS root extract was decreased by $4.3 \%$; however, the residue amount was significantly increased by $25.02 \%$ compared with the control sample. The experimental results concluded that the Trivedi Effect ${ }^{\circledR}$ Consciousness Energy Healing Treatment might have altered particle size, surface area, and thermal properties of WS root extract which would show better solubility, dissolution, absorption, bioavailability, and thermal stability compared to the control sample. This new form of WS root extract would be helpful to design more efficacious neutraceutical/pharmaceutical formulations for rejuvenate the body, restricting the aging process, immune busting, neuro-protection, antioxidant, inflammation, memory loss, insomnia, hepatoprotection, hypoglycemia, gastrointestinal issues, constipation, arthritis, cancer, skin conditions, Alzheimer's, Huntington's, and Parkinson's disorders, etc.

\section{Acknowledgement}

The authors are grateful to Central Leather Research Institute, SIPRA Lab. Ltd., Trivedi Science, Trivedi Global, Inc., Trivedi Testimonials, and Trivedi Master Wellness for their assistance and support during this work.

\section{References}

1. Kesarwani K, Gupta R, Mukerjee A (2013) Bioavailability enhancers of herbal origin: An overview. Asian Pac J Trop Biomed 3(4): 253-266.

2. Kulkarni SK, Dhir A (2008) Withania somnifera: An Indian ginseng. Prog Neuropsychopharmacol Biol Psychiatry 32(5): 1093-1105. 


\section{Journal of Natural \& Ayurvedic Medicine}

3. Singh N, Bhalla M, Jager P, Gilca M (2011) An overview on ashwagandha: A rasayana (rejuvenator) of Ayurveda. Afr J Tradit Complement Altern Med 8(5): 208-213.

4. Dar NJ, Hamid A, Ahmad M (2015) Pharmacologic overview of Withania somnifera, the Indian ginseng. Cell Mol Life Sci 72(33): 4445-4460.

5. Mir BA, Khazir J, Mir NA, Hasan T-ul, Koul S (2012) Botanical, chemical and pharmacological review of Withania somnifera (Indian ginseng): An Ayurvedic medicinal plant. Indian J Drugs Dis 1(6): 147-160.

6. Mishra LC, Singh BB, Dagenais S (2000) Scientific basis for the therapeutic use of Withania somnifera (Ashwagandha): A review. Altern Med Rev 5(4): 334346.

7. Kumar V, Dey A, Hadimani MB, Marcović T, Emerald $M$ (2015) Chemistry and pharmacology of Withania somnifera: An update. Tang (Humanitas Medicine) 5(1): e1.

8. Bolleddula J, Fitch W, Vareed SK, Nair MG (2012) Identification of metabolites in Withania sominfera fruits by liquid chromatography and high-resolution mass spectrometry. Rapid Commun Mass Spectrom 26(11): 1277-1290.

9. Mirjalili MH, Moyano E, Bonfill M, Cusido RM, Palazón J (2009) Steroidal lactones from Withania somnifera, an ancient plant for novel medicine. Molecules 14(7): 2373-2393.

10. Singh A, Duggal S, Singh H, Singh J, Katekhaye S (2010) Withanolides: Phytoconstituents with significant pharmacological activities. Int J Green Pharm 4(4): 229-237.

11. Chen LX, He H, Qiu F (2011) Natural withanolides: An overview. Nat Prod Rep 28(4): 705-740.

12. Budhiraja RD, Krishan P, Sudhir S (2000) Biological activity of withanolides. J Sci Ind Res 59: 904-911.

13. Kalepua S, Nekkanti V (2015) Insoluble drug delivery strategies: Review of recent advances and business prospects. Acta Pharmaceutica Sinica B 5(5): 442453.

14. Rein MJ, Renouf M, Cruz-Hernandez M, Actis-Goretta L, Thakkar SK, et al. (2013) Bioavailability of bioactive food compounds: A challenging journey to bioefficacy. Br J Clin Pharmacol 75(3): 588-602.

15. Trivedi MK, Branton A, Trivedi D, Nayak G, Wellborn BD, et al. (2017) Characterization of physicochemical, thermal, structural, and behavioral properties of magnesium gluconate after treatment with the Energy of Consciousness. International Journal of Pharmacy and Chemistry 3: 1-12.

16. Trivedi MK, Branton A, Trivedi D, Nayak G, Nykvist CD, et al. (2017) Evaluation of the physicochemical, spectral, and thermal properties of sodium selenate treated with the Energy of Consciousness (the Trivedi Effect ${ }^{\circledR}$. Advances in Bioscience and Bioengineering 5(1): 12-21.

17. Trivedi MK, Patil S, Shettigar H, Bairwa K, Jana S (2015) Spectroscopic characterization of chloramphenicol and tetracycline: An impact of biofield. Pharm Anal Acta 6(7): 395.

18. Trivedi MK, Branton A, Trivedi D, Shettigar H, Bairwa $\mathrm{K}$, et al. (2015) Fourier transform infrared and ultraviolet-visible spectroscopic characterization of biofield treated salicylic acid and sparfloxacin. Nat Prod Chem Res 3(5): 186.

19. Branton A, Jana S (2017) The use of novel and unique biofield energy healing treatment for the improvement of poorly bioavailable compound, berberine in male Sprague Dawley rats. American Journal of Clinical and Experimental Medicine 5(4): 138-144.

20. Trivedi MK, Mohan TRR (2016) Biofield energy signals, energy transmission and neutrinos. American Journal of Modern Physics 5(6): 172-176.

21. Rubik B, Muehsam D, Hammerschlag R, Jain S (2015) Biofield science and healing: history, terminology, and concepts. Glob Adv Health Med 4: 8-14.

22. Oschman J (2003) Energy medicine in therapeutics and human performance. philadelphia: Butterworth heinemann 1-12.

23. Barnes PM, Bloom B, Nahin RL (2008) Complementary and alternative medicine use among adults and children: United States, 2007. Natl Health Stat Report 10(12): 1-23.

24. Koithan M (2009) Introducing complementary and alternative therapies. J Nurse Pract 5(1): 18-20. 


\section{Journal of Natural \& Ayurvedic Medicine}

25. Trivedi MK, Tallapragada RM (2008) A transcendental to changing metal powder characteristics. Metal Powder Report 63(9): 22-28.

26. Trivedi MK, Nayak G, Patil S, Tallapragada RM, Latiyal $O$ (2015) Studies of the atomic and crystalline characteristics of ceramic oxide nano powders after bio field treatment. Ind Eng Manage 4(3): 161.

27. Trivedi MK, Branton A, Trivedi D, Nayak G, Mishra RK, et al. (2015) Characterization of physicochemical and thermal properties of biofield treated ethyl cellulose and methyl cellulose. International Journal of Biomedical Materials Research 3(6): 83-91.

28. Trivedi MK, Branton A, Trivedi D, Nayak G, Sethi KK, et al. (2016) Evaluation of isotopic abundance ratio in biofield energy treated nitrophenol derivatives using gas chromatography-mass spectrometry. American Journal of Chemical Engineering 4(3): 68-77.

29. Trivedi MK, Branton A, Trivedi D, Nayak G, Panda P, et al. (2016) Determination of isotopic abundance of ${ }^{13} \mathrm{C} /{ }^{12} \mathrm{C}$ or ${ }^{2} \mathrm{H} /{ }^{1} \mathrm{H}$ and ${ }^{18} \mathrm{O} /{ }^{16} \mathrm{O}$ in biofield energy treated 1-chloro-3-nitrobenzene (3-CNB) using gas chromatography-mass spectrometry. Science Journal of Analytical Chemistry 4(4): 42-51.

30. Trivedi MK, Branton A, Trivedi D, Nayak G, Mondal SC, et al. (2015) Evaluation of plant growth, yield and yield attributes of biofield energy treated mustard (Brassica juncea) and chick pea (Cicer arietinum) seeds. Agriculture Forestry \& Fisheries 4(6): 291-295.

31. Trivedi MK, Branton A, Trivedi D, Nayak G, Gangwar $M$, et al. (2015) Evaluation of Vegetative Growth Parameters in Biofield Treated Bottle Gourd (Lagenaria siceraria) and Okra (Abelmoschus esculentus). International Journal of Nutrition \& Food Sciences. 4(6): 688-694.

32. Trivedi MK, Branton A, Trivedi D, Shettigar H, Nayak G, et al. (2015) Antibiogram typing of biofield treated multidrug resistant strains of Staphylococcus species. American Journal of Life Sciences 3(5): 369-374.
33. Trivedi MK, Branton A, Trivedi D, Shettigar H, Nayak G, et al. (2015) Antibiogram, biochemical reactions and genotyping characterization of biofield treated Staphylococcus aureus. American Journal of BioScience 3(6): 212-220.

34. Trivedi MK, Patil S, Shettigar H, Gangwar M, Jana S (2015) In vitro evaluation of biofield treatment on cancer biomarkers involved in endometrial and prostate cancer cell lines. J Cancer Sci Ther 7(8): 253257.

35. Trivedi MK, Sethi KK, Panda P, Jana S (2017) A comprehensive physicochemical, thermal, and spectroscopic characterization of zinc (II) chloride using X-ray diffraction, particle size distribution, differential scanning calorimetry, thermogravimetric analysis/differential thermogravimetric analysis, ultraviolet-visible, and Fourier transform-infrared spectroscopy. International Journal of Pharmaceutical Investigation 7(1): 33-40.

36. Trivedi MK, Sethi KK, Panda P, Jana S (2017) Physicochemical, thermal and spectroscopic characterization of sodium selenate using XRD, PSD, DSC, TGA/DTG, UV-vis, and FT-IR. Marmara Pharmaceutical Journal 21(2): 311-318.

37. (1997) Desktop X-ray Diffractometer "MiniFlex+". The Rigaku Journal 14: 29-36.

38. Zhang T, Paluch K, Scalabrino G, Frankish N, Healy AM, et al. (2015) Molecular structure studies of (1S,2S)-2benzyl-2,3-dihydro-2-(1Hinden-2-yl)-1H-inden-1-ol. J Mol Struct 1083: 286-299.

39. Langford JI, Wilson AJC (1978) Scherrer after sixty years: A survey and some new results in the determination of crystallite size. J Appl Cryst 11: 102113.

40. Zhao Z, Xie M, Li Y, Chen A, Li G, et al. (2015) Formation of curcumin nanoparticles via solutionenhanced dispersion by supercritical $\mathrm{CO}_{2}$. Int J Nanomedicine 10: 3171-3181. 